\title{
IMPLIKASI TERBITNYA UNDANG-UNDANG NOMOR 23 TAHUN 2014 TERHADAP PEMBANGUNAN KESATUAN PENGELOLAAN HUTAN DI PROVINSI RIAU
}

\author{
Eno Suwarno, Ambar Tri Ratnaningsih, Enny Insusanty \\ Staf Pengajar Fakultas Kehutanan Universitas Lancang Kuning, \\ Jln. Yos Sudarso Km.8 Rumbai, Pekanbaru, Riau, Telp/Fax (0761) 54092 \\ Email : enosuwarno@gmail.com, ambar_trn@yahoo.com,annovisa@yahoo.com
}

\begin{abstract}
The issuance of the Law No. 23 of 2014 on Regional Government instead of Law No. 32 of 2004 carries implications for FMU development in the area. This study aims to (1) assess changes in the content of Law No. 23 of 2014 compared with the previous regulations in managing the affairs of the forestry sector; (2) assess the implications of these changes to the rules under which the current level is the reference FMU development; and (3) assess the implications of these changes to the processes of FMU development in Riau Province. The study was conducted in December 2014 May 2015, with research sites in the city of Pekanbaru and the district of Kampar, Riau Province. The method used is the content analysis of the rules and interviews with some stakeholders. The substantial changes of the Law No. 32/2004 to Law No. 23/2014, in the new regulations authorizes the establishment of the organization KPHL I KPHP everything under the authority of the provincial government, no longer under the authority of district governments. The implications of the transfer of authority, the regulations that the legal basis and the establishment of institutions KPHL / KPHP i.e. the Government Regulation (PP) No. 38/2007 and Rule of the Interior Minister (Permendagri) No. 61/2010 can not be a reference again. In addition it also affects the initiative and formation process KPHL / KPHP by Regency stagnated.
\end{abstract}

Keywords: The Law No. 23 of 2014 on Regional Government, Forest Management Unit (FMU), transfer of authority

\section{PENDAHULUAN}

Dalam kurun waktu lima tahun terakhir, pembangunan Kesatuan Pengelolaan Hutan (KPH) tengah menjadi program prioritas pemerintah. Hal ini tergambar dari sasaran strategis yang akan dicapai dalam pelaksanaan
Rencana Stategis Kementerian Kehutanan Tahun 2010-2014, yang mentargetkan ditetapkannya wilayah $\mathrm{KPH}$ di setiap provinsi dan terbentuknya $20 \%$ kelembagaan KPH. Pentingnya keberadaan organisasi $\mathrm{KPH}$ semakin dirasakan seiring dengan masih 
tingginya tingkat deforestasi dan degradasi hutan. Ditinjau dari perspektif tata kelola, ketiadaan organisasi pengelola di tingkat tapak ditengarai sebagai salah satu penyebab utama tidak dapat diatasinya permasalahanpermasalahan illegal logging, perambahan hutan, konflik lahan, dan kegagalan program-program rehabilitasi hutan. Oleh karena itu, pembangunan $\mathrm{KPH}$ dimaksudkan untuk mengatasi kelemahan sistem pengurusan hutan di masa lalu ini, agar keberadaannya di tingkat tapak dapat menjalankan keseluruhan tugas dan fungsi pengelolaan hutan.

Berdasarkan

pengalaman implementasi pembangunan $\mathrm{KPH}$ di lapangan, khususnya dalam pembangunan $\mathrm{KPH}$ model, ditemukan sejumlah kendala. Situasi umum yang terjadi di daerah saat ini adalah: 1) tidak seluruh Pemda memberi dukungan dalam pembangunan $\mathrm{KPH}$, terutama dalam pembentukan organisasi $\mathrm{KPH}$ karena memerlukan anggaran yang besar untuk menghidupkan organisasi tersebut; 2) terbatasnya pengertian dan pemahaman aparatur daerah terhadap fungsi dan manfaat $\mathrm{KPH}$ bagi pembangunan kehutanan dan 3) terbatasnya SDM yang memahami dan mempunyai kapabilitas untuk menjalankan organisasi KPH (Kartodihardjo et al., 2011). Implikasi dari semua kendala tersebut adalah terhambatnya proses pembentukan organisasi dan operasionalisasi $\mathrm{KPH}$ di daerah (Suwarno et al., 2015). Selain itu salah satu isu penting yang sering mencuat dalam berbagai diskusi -forum sosialisasi, workshop, rapat kerja, dan sebagainya- adalah masalah peraturan perundang-undangan. Terbitnya UU No. 23/2014 tentunya menjadi landasan baru bagi pelaksanaan pembangunan kehutanan dan secara khusus bagi pembangun KPH di di Provinsi Riau. Oleh karena itu terkait diterbitkannya UU ini, diperlukan suatu kajian sejauh mana perubahan-perubahan yang terdapat dalam UU baru dibandingkan dengan UU dan peraturan turunan yang berlaku sebelumnya. Selanjutnya perlu dilakukan analisis bagaimana implikasinya terhadap proses-proses pembanguan KPH di Provinsi Riau yang tengah berlangsung saat ini, serta untuk proses pembangunan $\mathrm{KPH}$ tahap berikutnya.

Penelitian ini bertujuan untuk (1) Mengkaji perubahan substansi antara isi Undang-Undang Nomor 23 tahun 2014 dengan 
sebelumnya dalam pengaturan urusan bidang kehutanan; (2) Mengkaji implikasi perubahan tersebut terhadap peraturanperaturan tingkat di bawahnya (PP dan Permen) yang saat ini menjadi acuan pembangunan $\mathrm{KPH}$; dan (3) Mengkaji implikasi perubahan tersebut terhadap proses-proses pembangunan $\mathrm{KPH}$ di Provinsi Riau.

\section{TINAJAUAN PUSTAKA Konsep KPH}

Pengertian KPH sebagai suatu unit pengelolaan hutan secara formal mulai muncul di dalam Undang-Undang Nomor 41 Tahun 1999 tentang Kehutanan, yaitu pada penjelasan pasal 17: "Yang dimaksud dengan unit pengelolaan adalah kesatuan pengelolaan hutan terkecil sesuai fungsi pokok dan peruntukannya, yang dapat dikelola secara efisien dan lestari". Sedangkan Castaneda (2000) mendefinisikan $\mathrm{KPH}$ sebagai unit pengelolaan hutan yang arealnya telah ditetapkan dengan batas-batas yang jelas, dimana sebagian besar arealnya ditutupi oleh hutan, dikelola untuk jangka panjang, dan memiliki sejumlah tujuan yang jelas yang dituangkan ke dalam rencana pengelolaan hutan. Dengan demikian maka $\mathrm{KPH}$ adalah strategi manajemen hutan berupa pembagian areal lahan hutan ke dalam unit-unit wilayah pengelolaan berdasarkan kriteria tertentu.

Luas wilayah satu unit KPH berkisar antara 5000 ha -700.000 ha (lihat Dir WP3H 2012). Penetapan luas wilayah $\mathrm{KPH}$ tersebut sangat dipengaruhi oleh luas dan sebaran wilayah hutan yang ada pada masing-masing provinsi dan kabupaten/kota di Indonesia. Menurut Peraturan Pemerintah Nomor 6 Tahun 2007, KPH meliputi KPH Konservasi (KPHK), KPH Lindung (KPHL), dan $\mathrm{KPH}$ Produksi (KPHP) ${ }^{1}$. Secara konseptual, menurut Kartodihardjo dan Suwarno (2014), proses pembangunan KPH sesungguhnya merupakan proses pergeseran institusi (institutional change), dimana dalam proses pergeseran institusi terdapat beberapa pokok perubahan fundamental yang menjadi filosofi dasarnya, yaitu: (a) Perubahan nilai (value system) dan cara berpikir; (b) Perubahan batas yurisdiksi (jurisdiction boundary); (c) Pengelolaan yang berbasis output secara nyata; dan (d) Peningkatan transparansi dan akuntabilitas. 
Prosedur pembentukan wilayah $\mathrm{KPH}$ diatur dalam Peraturan Menteri Kehutanan (Permenhut) Nomor P.6/Menhut-II/2009

Pembentukan

Wilayah

Berdasarkan peraturan pembentukan $\mathrm{KPH}$ melalui empat tahap, yaitu: tahap 1, Usulan Rancang bangun $\mathrm{KPH}$ oleh Dinas Kehutanan Provinsi; tahap 2, Arahan pencadangan wilayah $\mathrm{KPH}$ oleh Kementerian Kehutanan; tahap 3, Usulan Penetapan KPH dari Dinas Kehutanan Provinsi; dan tahap akhir, Penetapan wilayah $\mathrm{KPH}$ oleh Kemenhut.

Setelah penetapan wilayah $\mathrm{KPH}$ maka harus segera diikuti dengan penetapan organisasi yang akan mengelola $\mathrm{KPH}$. KPH dikelola oleh sebuah organisasi pemerintah yang menyelenggarakan fungsi pengelolaan hutan di tingkat tapak (site level). Berdasarkan PP No. 6/2007 jo PP No $3 / 2008$, organisasi KPHK dibentuk dan ditetapkan oleh Kemenhut, sementara berdasarkan Permendagri No. 61/2010 organisasi pengelola KPHL dan KPHP dibentuk dan ditetapkan oleh Pemerintah Daerah. Pembentukan organisasi KPHL dan KPHP yang wilayah kerjanya lintas Kabupaten/Kota dalam satu provinsi ditetapkan dengan Peraturan Daerah
Provinsi.Pembentukan organisasi KPHL dan KPHP yang wilayah kerjanya dalam satu Kabupaten/Kota ditetapkan dengan Peraturan Daerah Kabupaten/Kota.

\section{Implikasi Perubahan Peraturan}

Secara hirarkis Kiser dan Ostrom (1982) membagi peraturan ke dalam tiga tingkatan, yaitu aturan konstitusional (UUD), aturan pilihan kolektif (UU), dan aturan operasional (PP, Permen, dst). Secara normatif, aturan yang lebih rendah akan bersarang (mengacu) kepada seperangkat aturan yang lebih tinggi. Dengan demikian maka perubahan pada satu tingkat peraturan akan sangat ditentukan oleh batas-batas yang dimungkinkan dari lingkup peraturan di atasnya, sementara perubahan pada peraturan yang lebih tinggi hampir selalu akan berdampak luas kepada perubahan peraturan tingkat di bawahnya. Menurut Blomquist (2006), komponen peraturan berperan dalam membentuk situasi aksi dengan cara mempengaruhi insentif dan pilihan yang tersedia bagi pada aktor, kemudian aktor yang rasional akan meresponnya dengan cara berperilaku dan mengadopsi strategi tertentu, yang selanjutnya akan mempengaruhi hasil. Oleh karena itu menurut Blomquist, 
dengan memodifikasi peraturan dapat mendororng aktor untuk berperilaku dan mengadopsi strategi tertentu sehingga berpotensi menghasilkan hasil yang berbeda. Menurut Ostrom (2008), modifikasi peraturan pada dasarnya dimaksudkan untuk menemukan kombinasi yang lebih efektif dibanding kombinasi yang lainnya.

\section{METODE PENELITIAN Lingkup Kegiatan}

Lingkup kegiatan penelitian ini terdiri dari dua jenis kegiatan, yaitu:

1) Kajian dokumen peraturan, dimana peraturan yang akan dikaji terdiri dari:

1. Undang-Undang Nomor 23 tahun 2014 tentang Pemerintahan Daerah;

2. Undang-Undang Nomor 32 tahun 2004 tentang Pemerintahan Daerah;

3. Peraturan Pemerintah Nomor 38 tahun 2007 tentang Pembagian Urusan Pemerintahan antara Pemerintah, Pemerintah Daerah Provisnsi dan Pemerintah Daerah Kabupaten/Kota;

4. Peraturan Pemerintah Nomor 3 tahun 2007 juncto Peraturan Pemerintah Nomor 6 tahun 2008 tentang Tata Hutan dan Penyusunan Rencana
Pengelolaan Hutan serta Pemanfaatan Hutan;

5. Peraturan Menteri Dalam Negeri Nomor 61 tahun 2010 tentang Pedoman Organisasi dan Tata Kerja KPHL dan KPHP; dan

2) Wawancara terhadap aparatur Dinas Kehutanan Provinsi Riau dan Dinas Kehutanan Kabupaten Kampar, serta tiga KPH di Provinsi Riau yaitu KPHP Tasik Besar Serkap, KPHP Minas Tahura, dan KPHP Kampar Kiri.

\section{Waktu dan Lokasi Penelitian}

Penelitian dilaksanakan antara bulan Desember 2014 sampai dengan Mei 2015. Lokasi penelitian di Kota Pekanbaru dan Kabupaten Kampar, Provinsi Riau.

\section{Metode Pengumpulan dan Analisis Data}

- Metode Pengumpulan Data

- Data terkait isi peraturan yang dianalisis dikumpulkan dari internet dengan cara mengunjungi situs-situs yang menyediakan peraturan yang dibutuhkan.

- Data tentang pandangan dan tanggapan aparatur terkait dari Dinas Kehutanan Provirsi Riau, Dinas Kehutanan Kabupaten 
Kampar, KPHP Tasik Besar Serkap, KPHP Minas Tahura, dan KPHP Kampar Kiri dikumpulkan dengan metode wawancara semi terstruktur.

\section{- Metode Analisis Data}

- Analisis peraturan dilakukan dengan metode analisis isi (content analysis) dengan jalan mengidentifikasi karakteristik isi peraturan yang dibentuk melalui teks. Substansi yang dianalisis adalah tentang pembagian kewenangan antara pemerintah, pemerintah provinsi, dan pemerintah kabupaten / kota, dan tata hubungan antar tingkatan peraturan (Undang-Undang Peraturan Pemerintah Peraturan Menteri). Analisis terhadap pandangan dan tanggapan dari aparatur kehutanan daerah menggunakan analisis deskriptif, yang menggambarkan aspek pemahaman dan sikap terhadap isi peraturan yang baru.

\section{HASIL DAN PEMBAHASAN Analisis Peraturan}

Analisis peraturan dilakukan terhadap lima buah peraturan, yaitu (1) Undang-Undang Nomor 23 tahun 2014 tentang Pemerintahan Daerah; Undang-Undang Nomor 32 tahun 2004 tentang Pemerintahan Daerah; Peraturan Pemerintah Nomor 38 tahun 2007 tentang Pembagian Urusan Pemerintahan antara Pemerintah, Pemerintah Daerah Provisnsi dan Pemerintah Daerah Kabupaten/Kota; (4) Peraturan Pemerintah Nomor 3 tahun 2007 juncto Peraturan Pemerintah Nomor 6 tahun 2008 tentang Tata Hutan dan Penyusunan Rencana Pengelolaan Hutan serta Pemanfaatan Hutan; dan (5) Peraturan Menteri Dalam Negeri Nomor 61 tahun 2010 tentang Pedoman Organisasi dan Tata Kerja KPHL dan KPHP.

\section{UU No. 32 Tahun 2004 tentang}

\section{Pemerintahan Daerah}

- Di dalam UU No. 32/2004 pembagian urusan pemerintahan Bidang Kehutanan tidak dirinci namun termasuk ke dalam kelompok yang akan diatur secara khusus melalui PP (Pasal 14:3).

\section{PP No. 38 Tahun 2007 tentang Pembagian Urusan Pemerintahan antara Pemerintah, Pemerintah Daerah Provinsi, dan Pemerintah Kabupaten/Kota}

- Di dalam PP No. 38/2007 sebagai penjabaran dari UU No. 32/2004, pada 
Pasal 2(4) dinyatakan bahwa urusan kehutanan adalah urusan pemerintahan yang dibagi bersama antar tingkatan pemerintahan (konkuren).

- Urusan kehutanan termasuk ke dalam kelompok urusan pilihan (Pasal 7:4).

- Pada Lampiran Bagian AA poin 8 dinyatakan bahwa: (a) wewenang Pemerintah adalah menetapkan norma, standar, prosedur, dan kriteria, dan pelaksanaan penetapan pembentukan wilayah pengelolaan hutan $(\mathrm{KPH})$, penetapan wilayah $\mathrm{KPH}$ dan institusi $\mathrm{KPH}$, serta arahan pencadangan; (b) wewenang Pemerintah Daerah Provinsi adalah melaksanakan penyusunan rancang bangun, pembentukan dan pengusulan penetapan KPHL dan KPHP serta pertimbangan teknis institusi KPHL/KPHP; dan (c) wewenang Pemerintah Daerah Kabupaten/Kota adalah memberi pertimbangan penyusunan rancang bangun dan pengusulan pembentukan KPHL dan KPHP, serta institusi KPHL/KPHP.

PP No.6/2007 Jo No. 3/2008 tentang Tata Hutan dan Penyusunan Rencana Pengelolaan Hutan, serta Pemanfaatan Hutan
- Di dalam PP No. 6/2007 Jo PP 3/2008 Pasal 8(1) dinyatakan bahwa Menteri menetapkan organisasi KPHK, KPHL, dan KPHP. Berdasarkan Pasal 8(2), Penetapan Organisasi KPHL dan KPHP dilakukan berdasarkan: (a) usulan dari pemerintah provinsi, dalam hal KPHP atau KPHL berada dalam lintas kabupaten/kota; (b) usulan dari pemerintah kabupaten/ kota, dalam hal KPHP atau KPHL berada dalam kabupaten/kota; (c) pertimbangan teknis dari pemerintah provinsi.

Permendagri No.61/2010 tentang Pedoman Organisasi dan Tata Kerja KPHL dan KPHP di Daerah

- Di dalam Permendagri No.61/2010 Pasal 2(2) dinyatakan bahwa pembentukan KPHL dan KPHP yang wilayah kerjanya lintas Kabupaten/Kota dalam satu provinsi ditetapkan dengan Peraturan Daerah Provinsi; bunyi ayat (3) Pembentukan $\mathrm{KPHL}$ dan KPHP yang wilayah kerjanya dalam satu Kabupaten/Kota ditetapkan dengan Peraturan Daerah Kabupaten/Kota. Kemudian bunyi Pasal 3(1) KPHL dan KPHP Provinsi sebagaimana dimaksud dalam Pasal 2 ayat (2) berada di bawah dan bertanggung jawab kepada Gubernur 
melalui Sekretaris Daerah; dan ayat (2) KPHL dan KPHP Kabupaten/Kota sebagaimana dimaksud dalam Pasal 2 ayat (3) berada di bawah dan bertanggungjawab kepada Bupati/Walikota melalui Sekretaris Daerah.

\section{UU No. 23 Tahun 2014 tentang}

\section{Pemerintahan Daerah}

- Di dalam UU No. 23/2014 Pasal 14(1): Penyelenggaraan

Urusan Pemerintahan bidang kehutanan dibagi antara Pemerintah Pusat dan Daerah Provinsi; (2) Urusan Pemerintahan yang berkaitan dengan pengelolaan taman hutan raya kabupaten/kota menjadi kewenangan Daerah kabupaten/kota.

- Pasal 404: serah terima personel, pendanaan, sarana dan prasarana, serta dokumen (P3D) sebagai akibat pembagian urusan pemerintahan antara Pemerintah Pusat, daerah provinsi dan daerah kabupaten/kota yang diatur berdasarkan UndangUndang ini dilakukan paling lama 2 (dua) tahun terhitung sejak UndangUndang ini diundangkan.

- Lampiran BB Pembagian Urusan Pemerintahan Bidang Kehutanan, dinyatakan bahwa pengelolaan hutan oleh Pemerintah meliputi: a. Penyelenggaraan tata hutan; b. Penyelenggaraan rencana pengelolaan hutan (di dalamnya termasuk pembentukan wilayah $\mathrm{KPH}$ ); c. Penyelenggaraan pemanfaatan hutan dan penggunaan kawasan hutan; d. Penyelenggaraan rehabilitasi dan reklamasi hutan; e. Penyelenggaraan perlindungan hutan; f. Penyelenggaraan pengolahan dan penatausahaan hasil hutan; $g$. Penyelenggaraan pengelolaan kawasan hutan dengan tujuan khusus (KHDTK).

- Pengelolaan hutan oleh Pemerintah Provinsi melipputi: a. Pelaksanaan tata hutan kesatuan pengelolaan hutan kecuali pada kesatuan pengelolaan hutan konservasi (KPHK); b. Pelaksanaan rencana pengelolaan kesatuan pengelolaan hutan kecuali pada kesatuan pengelolaan hutan konservasi (KPHK); c. Pelaksanaan pemanfaatan hutan di kawasan hutan produksi dan hutan lindung, meliputi: (1) Pemanfaatan kawasan hutan, (2) Pemanfaatan hasil hutan bukan kayu, (3) Pemungutan hasil hutan; Pemanfaatan jasa lingkungan kecuali pemanfaatan penyimpanan dan/atau penyerapan karbon; d. Pelaksanaan 
rehabilitasi di luar kawasan hutan negara; e. Pelaksanaan perlindungan hutan di hutan lindung, dan hutan produksi; f. Pelaksanaan pengolahan hasil hutan bukan kayu; $g$. Pelaksanaan pengolahan hasil hutan kayu dengan kapasitas produksi < 6000 m³/tahun; h. Pelaksanaan pengelolaan KHDTK untuk kepentingan religi.

- Keterangan: Semua rincian tugas pengelolaan hutan di atas dilaksanakan oleh organisasi/institusi $\mathrm{KPH}(\mathrm{KPHL} / \mathrm{KPHP})$

Berdasarkan identifikasi terhadap isi peraturan di atas, perubahanperubahan mendasar dalam pembagian kewenangan urusan kehutanan (dan secara khusus terkait pembangunan $\mathrm{KPH}$ ) adalah sebagai berikut:

1. Di dalam peraturan lama, kewenangan membentuk institusi KPHL dan KPHP, untuk kawasan hutan lintas kabupaten/kota menjadi kewenangan pemerintah daerah provinsi; dan untuk kawasan hutan dalam satu wilayah kabupaten/kota menjadi kewenangan pemerintah daerah kabupaten/kota.

2. Di dalam peraturan baru (UU No.23/2014) kewenangan membentuk institusi KPHL dan KPHP semuanya menjadi kewenangan pemerintah provinsi; tidak ada lagi yang menjadi kewenangan pemerintah daerah kabupaten/kota, kecuali pengelolaan taman hutan raya (Tahura) yang ada di wilayahnya.

3. Serah terima personel, pendanaan, sarana dan prasarana, serta dokumen (P3D) sebagai akibat perubahan pembagian urusan pemerintahan antara Pemerintah Pusat, daerah provinsi dan daerah kabupaten/kota dilakukan paling lama 2 (dua) tahun terhitung sejak Undang-Undang ini diundangkan, yaitu paling lambat tanggal 2 Oktober 2016.

\section{Hasil Wawancara}

Wawancara dilakukan kepada sejumlah aparatur kehutanan di tingkat provinsi (Kepala Dinas Kehutanan Provinsi Riau, Kepala KPHP Tasik Besar Serkap, dan Kepala KPHP Minas Tahura) dan di tingkat kabupaten (Sekretaris dan tiga Kepala Bidang di Dinas Kehutanan Kabupaten Kampar, dan Kepala KPHP Kammpar Kiri). Butirbutir hasil wawancara diangkum sebagai berikut:

- Setelah terbitnya UU No. 23/2014, untuk urusan pemerintahan bidang 
kehutanan belum ada pembahasan dan koordinasi antara Pemerintah Daerah Provinsi Riau dengan Pemerintah Kabupaten/Kota.

- Dalam merespon UU baru ini secara umum sikap pemerintah daerah (Provinsi dan Kabupaten/Kota) pada dasarnya taat hukum, dan bersifat menunggu pedoman implementasinya atau peraturan operasionalnya (PP dan Permen).

- KPHP Kampar Kiri sebagai KPH yang dibentuk Pemeritah Kabupaten Kampar untuk tahun 2015 masih tetap melanjutkan aktivitas sesuai dengan perencanaan yang sudah dibuat (RKT dan RK-KPH). Namun untuk tahun-tahun selanjutnya menunggu ketentuan yang akan dibuat pemerintah.

- Bila urusan pemerintahan bidang kehutanan semuanya ditarik ke provinsi, kecuali pengelolaan Tahuran kabupaten/kota, maka keberadaan Dinas Kehutanan Kabupaten/Kota menjadi tidak urgen lagi. Diperkirakan tahun 2017 Dinas Kehutanan di Kabupaten Kampar sudah tidak ada lagi.

- Bagi KPHP Tasik Besar Serkap dan KPHP Minas Tahura, diterbitkannya UU No. 23/2014 tidak berpengaruh terhadap kedudukan institusi/kelembagaan yang sudah ada, mengingat baik institusi maupun personilnya sudah di bawah Pemdaprov Riau.

- Bila seluruh KPH di Provinsi Riau (menurut rancang bangun $\mathrm{KPH}$ akan dibentuk $32 \mathrm{KPH}$ ) menjadi $\mathrm{KPH}$ Provinsi, dan semuanya menjadi SKPD, maka hal ini akan sangat menjadi beban pemerintah daerah Provinsi Riau.

- Bila masing-masing menjadi SKPD mandiri dan otonom, maka jumlah SKPD di provinsi Riau akan menjadi sekitar 90 SKPD. Hal ini menjadi kurang rasional, mengingat urusan pemerintahan bidang lain hanya diurus oleh 1 atau 2 SKPD, sementara bidang kehutanan akan diurus oleh 33 SKPD. Maka yang lebih rasional adalah adanya kesatuan $\mathrm{KPH}$ untuk seluruh $\mathrm{KPH}$ di provinsi Riau, dimana insitusi di tingkat Provinsi dapat berupa SKPD eselon 2 yang membawahi $\mathrm{KPH}$ $\mathrm{KPH}$ (eselon 3) di seluruh provinsi Riau.

- Merespon Surat Edaran Mendagri No. $120 / 253 / S j$ tanggal 16 Januari 2015 tentang Penyelenggaraan Urusan 
Pemerintahan Setelah Ditetapkan UU No. 23 Tahun 2014 tentang Pemerintah Daerah, Pemkab Kampar telah melakukan rapat pada tanggal 16 Maret 2015 yang dipimpin oleh Sekretaris Daerah. Keputusannya antara lain segera membentuk tim inventarisasi personel, pendanaan, sarana dan prasarana, serta dokumen (P3D).

Hasil wawancara tersebut menunjukan bahwa respon pemerintah daerah Kabupaten Kampar terhadap pengalihan kewenangan urusan kehutanan dari pemkab/kota kepada pemprov yang diatur dalam UU No. 23/2014 bersikap menerima. Hal ini sebagai konsekwensi logis dari azas taat hukum terhadap sistem tata negara dalam bingkai Negara Kesatuan Republik Indonesia (NKRI). Sikap menerima ini selain dinyatakan secara lisan, juga ditunjukkan dengan langkahlangkah yang telah ditempuh untuk melaksanakan instruksi SE Mendagri No. 120/253/Sj. Pemda Kampar telah melakukan rapat pada tanggal 16 Maret 2015 yang dipimpin oleh Sekretaris Daerah. Keputusannya antara lain segera membentuk tim inventarisasi personel, pendanaan, sarana dan prasarana, serta dokumen (P3D).

Implikasi terhadap inisiatif dan proses-proses pembangunan KPHL/KPHP oleh pemerintah kabupaten/kota lebih bersifat tehnis saja. Tentunya tidak akan ada inisiatif pembentukan KPHL/KPHP baru, demikian juga alokasi anggaran dan pemenuhan SDM untuk KPHP yang sudah terbentuk. Baik pemerintah Kabupaten Kampar maupun pemerintah Provinsi Riau sama-sama menunggu peraturan turunan untuk menindaklanjuti ketentuan UU No. 23/2014, yaitu berupa PP dan Permen.

\section{KESIMPULAN DAN SARAN}

Perubahan substansial dari UU No. $32 / 2004$ kepada UU No. $23 / 2014$, di dalam peraturan baru, kewenangan pembentukan institusi KPHL/KPHP semuanya menjadi kewenangan pemerintah provinsi, tidak ada lagi yang menjadi kewenangan pemerintah kabupaten/kota, kecuali pengelolaan Taman Hutan Raya (Tahura) yang ada di wilayahnya.

Implikasi dari perpindahan kewenangan, maka peraturan yang menjadi dasar hukum pembentukan institusi KPHL dan KPHP yaitu PP No. 
38/2007 dan Permendagri No. 61/2010 (turunan dari UU No. 32/2004) tidak bisa diacu lagi. Peraturan tersebut harus segera diganti dengan PP dan Permen baru yang mengacu kepada UU No. 23/2014. Dalam masa transisi (2 tahun), apabila pemerintah provinsi akan membentuk institusi KPHL/KPHP, dapat mengacu kepada PP No. 41/2007 tentang Organisasi Perangkat Daerah.

Perpindahan kewenangan berimplikasi kepada inisiatif dan prosesproses pembentukan KPHL/KPHP oleh pemkab/kota mengalami stagnasi. Antara lain pada KPHP Kampar Kiri (sebagai KPH Pemdakab Kampar), saat ini sedang dalam proses penyiapan serah terima personel, pendanaan, sarana dan prasarana, serta dokumen (P3D) kepada Pemprov Riau Sementara pemerintah Provinsi Riau sendiri masih menunggu pedoman lebih lanjut untuk menindaklanjuti serah-terima $\mathrm{KPH}$ tersebut.

\section{Berdasarkan}

butir-butir kesimpulan di atas maka disarankan kepada pemerintah pusat agar segera membuat Peraturan Pemerintah (PP) dan Peraturan Menteri (Permen) sebagai penjabaran dari UU No. 23/2014 untuk acuan yang lebih operasional bagi pemerintah daerah. Dalam hubungannya dengan pembangunan institusi KPHL dan KPHP di daerah, hal yang paling mendasar adalah menyangkut tata hubungan kerja antar instansi pemerintah, bentuk organisasi, dan eselonisasi di dalam organisasi KPHL/KPHP. Adapun saran bagi Pemerintah Provinsi Riau dan Pemerintah Kabupaten/Kota di Provinsi Riau, sebaiknya segera melakukan koordinasi dan langkah-langkah penyiapan serah terima personil, pendanaan, sarana-prasarana, dan dokumen (P3D).

\section{UCAPAN TERIMA KASIH}

Tim peneliti mengucapkan terima kasih kepada Lembaga Penelitian dan Pengabdian Masyarakat (LPPM) Universitas Lancang Kuning, yang telah membiaya penelitian ini melalui skim APBU tahun anggaran 2014/2015.

\section{DAFTAR PUSTAKA}

Blomquist W. 2006. The Policy Process and Large-N Comparative Studies. In Sabatier PA, editor. Theories of the Policy Process. Boulder, CO (US): Westview Press.

Castañeda F. 2000. Why national and forest management unit level criteria and indicator for sustainable management of the dry forest in Asia?. in: Cheng TL, Durst PB, 
editors. Development of nationallevel criteria and indicator for sustainable management of the dry forest in Asia: background paper. Rap Publication, Bangkok, Thailand (TH). 1-22 June 2000.

[Dir WP3H] Direktorat Wilayah Pengelolaan dan Penyiapan Areal Pemanfaatan Kawasan Hutan, Direktorat Jenderal Planologi Kehutanan, Kementerian Kehutanan (ID). 2012. Data dan Informasi Kesatuan Pengelolaan Hutan (KPH) Tahun 2012. Jakarta: Direktorat Wilayah Pengelolaan dan Penyiapan Areal Pemanfaatan Kawasan Hutan, Direktorat Jenderal Planologi Kehutanan.

Kartodihardjo, H., Nugroho, B., \& Putro, H.P. (2011). Pembangunan kesatuan pengelolaan hutan (KPH): konsep, peraturan perundangan dan implementasi. Jakarta: Direktorat Jenderal Planologi Kehutanan.

Kartodihardjo H, Suwarno E. 2014. Pengarusutamaan Kesatuan Pengelolaan Hutan (KPH) dalam Kebijakan dan Pelaksanaan Perizinan Kehutanan. Jakarta (ID): Direktorat Wilayah Pengelolaan dan Penyiapan Areal Pemanfaatan Kawasan Hutan Direktorat Jenderal Planologi Kehutanan.

Kiser, Larry L., and Elinor Ostrom. 1982. The Three Worlds of Action: A Metatheoretical Synthesis of Institutional Approaches. In Strategies of Political Inquiry, ed. Elinor Ostrom, 179-222. Beverly Hills, California (US): Sage.
Ostrom, E. 2008. Institutions and the environment. Economic Affairs. 28(3):24-31

Ostrom E. 2005. Understanding Institutional Diversity. Princeton (US): Princenton University Press.

Peraturan Menteri Kehutanan Nomor P.6/Menhut-II/2009 tentang Pembentukan Wilayah KPH.

Peraturan Pemerintah Republik Indonesia Nomor 3 Tahun 2008 tentang Perubahan Atas Peraturan Pemerintah Nomor 6 Tahun 2007 tentang Tata Hutan dan Penyusunan Rencana Pengelolaan Hutan Serta Pemanfaatan Hutan.

Peraturan Pemerintah No. 6 Tahun 2007 tentang Tata Hutan dan Penyusunan Rencana Pengelolaan Hutan serta Pemanfaatan Hutan.

Suwarno, E. Kartodihardjo, $\mathrm{H}$. Kolopaking, ML. Soedomo, S. 2015. Penggunaan Konsep RulesIn-Use Ostrom Dalam Analisis Peraturan Pembentukan Organisasi Kesatuan Pengelolaan Hutan. Jurnal Analisis Kebijakan Kehutanan 12(1): 13-26 